\title{
Kenaikan Omzet UMKM Makanan dan Minuman di Kota Bogor Pasca Sertifikasi Halal
}

\section{The Increase of Food and Beverage MSME's Total Revenue in Bogor City Post Halal Certification}

\author{
Hana Khairunnisa ${ }^{1}$, Deni Lubis ${ }^{2}$, Qoriatul Hasanah ${ }^{3}$ \\ ${ }^{1}$ Institut Pertanian Bogor, Jalan Raya Dramaga, Bogor 16680, hana.khairunnisa29@gmail.com \\ ${ }^{2}$ Institut Pertanian Bogor, Jalan Raya Dramaga, Bogor 16680, denilubis@gmail.com \\ ${ }^{3}$ Institut Pertanian Bogor, Jalan Raya Dramaga, Bogor 16680, qoriatul@apps.ipb.ac.id
}

\begin{abstract}
Halal certification is one of the company's strategy that aims to retain their consumers and become a difference with competitors and to give added value for product. Most of the researchers have proved that halal certificates affect big companies' total revenue. However, there are not many studies that have proved that halal certificate would affect the total revenue of micro, small, and medium enterprises (MSMEs), especially in Bogor City. This research aims to determine the characteristics of MSMES' owners and their business, analyze the changes of MSME's total revenue before and after owning a halal certificate, and the factors that affect MSMEs' total revenue after owning a halal certificate. The questionnaire data were collected through an interview with 40 food and beverage MSMEs' owners who have halal certificates in Bogor City. This research uses descriptive analysis, paired sample t-test, and multiple linear regression analysis as the analysis methods. Results based on this research showed that there was a difference in the total revenue of MSMEs before and after owning a halal certificate. The factors that have positive and significant effects of MSMEs' total revenue influences are capital, work hours, length of business, and a dummy of promotion.
\end{abstract}

Keywords: Halal certification, multiple linear regression, paired sample t-test, total revenue of MSMEs' food and beverage

\begin{abstract}
Abstrak. Sertifikasi halal merupakan sebuah langkah strategis bagi perusahaan untuk tetap mempertahankan konsumen serta menjadi pembeda dengan perusahaan pesaing dan memberikan nilai tambah bagi produk. Sebagian besar penelitian terdahulu telah membuktikan sertifikat halal berpengaruh terhadap perolehan omzet usaha berskala besar. Namun, belum banyak penelitian yang membuktikannya terhadap UMKM khususnya di Kota Bogor. Penelitian ini bertujuan untuk mengetahui karakteristik umum pemilik UMKM dan karakteristik usahanya, menganalisis perubahan perolehan omzet sebelum dan sesudah memiliki sertifikat halal, dan faktor-faktor yang memengaruhi peningkatan omzet UMKM setelah memiliki sertifikat halal. Data penelitian dikumpulkan melalui proses wawancara kepada 40 pelaku UMKM makanan dan minuman yang memiliki sertifikat halal di Kota Bogor. Metode analisis yang digunakan yaitu analisis deskriptif, uji-t sampel berpasangan dan analisis regresi linear berganda. Berdasarkan hasil penelitian, terdapat perubahan omzet UMKM sebelum dan sesudah memiliki sertifikat halal. Faktor-faktor yang memengaruhi peningkatan perolehan omzet UMKM setelah memiliki sertifikat halal secara positif dan signifikan adalah modal, jam kerja, lama usaha, dan dummy promosi.
\end{abstract}

Kata kunci: Omzet UMKM makanan dan minuman, regresi linear berganda, sertifikasi halal, uji-t sampel berpasangan

\section{PENDAHULUAN}

Halal merupakan segala kebutuhan dalam penggunaan benda-benda seperti makanan, minuman dan obat-obatan yang tidak mengandung/tercampur dengan sesuatu yang diharamkan (Sucipto, 2012). Ketersediaan produk halal di Indonesia adalah hak konsumen Muslim yang harus dipenuhi oleh negaranya. Permintaan terhadap kebutuhan pangan dipengaruhi oleh agama/kepercayaan seseorang (Mullen, 2000). Konsumen Muslim diwajibkan mengonsumsi sesuatu yang halal sesuai aturan yang tercantum dalam Quran dan sunah. Salah satu upaya yang dapat dilakukan oleh pemerintah di Indonesia untuk melindungi penduduknya dari produk nonhalal adalah dengan kehadiran sertifikasi 
halal produk. Kebijakan tersebut diatur pada Undang-Undang No. 33 Tahun 2014 tentang Jaminan Produk Halal (UU-JPH). Seluruh produk yang masuk, beredar dan diperdagangkan di Indonesia wajib memiliki sertifikat halal. Berdasarkan UU-JPH, sertifikat halal resmi diterbitkan oleh Badan Penyelenggara Jaminan Produk Halal (BPJPH) dan bersifat wajib (mandatory).

Indonesia adalah negara yang tercatat memiliki jumlah penduduk beragama Islam terbesar di dunia, di mana $87.1 \%$ jumlah penduduknya adalah Muslim (Pew Research Center, 2015). Sehingga dapat dikatakan, konsumen terbesar yang memengaruhi besar permintaan di pasar dan perekonomian Indonesia adalah Muslim. Menurut State of the Global Islamic Economy Report (2019), pada tahun 2018 penduduk Muslim di Indonesia secara global mengeluarkan biaya sebanyak US\$1.4 triliun pada sektor makanan dan minuman, serta berpeluang mencapai US\$2.2 triliun pada tahun 2024. Besarnya angka tersebut dapat dipengaruhi berdasarkan pengetahuan konsumen terhadap produk halal dan norma religius yang dimiliki konsumen (Rochmanto \& Widiyanto, 2015). Oleh karena itu, sangat penting untuk adanya ketersediaan produk pada sektor makanan dan minuman halal di Indonesia.

Ketersediaan produk kebutuhan konsumen dapat dipenuhi dengan kehadiran usaha industri. Perusahaan industri yang berdiri di Indonesia didominasi oleh para pelaku Usaha Mikro, Kecil dan Menengah (UMKM) yang ditunjukkan dengan data jumlah unit usaha di Indonesia oleh Kementerian Koperasi dan UKM (Kemenkop \& UKM, 2018) pada Tabel 1. Tabel 1 menunjukkan jumlah UMKM yang tercatat di Indonesia sebanyak 64,194,057 unit usaha atau $99.99 \%$.

Tabel 1 Jumlah unit usaha, tenaga kerja dan Pendapatan Domestik Bruto (PDB) atas dasar harga berlaku tahun 2018 di Indonesia

\begin{tabular}{ccccccc}
\hline Unit Usaha & $\begin{array}{c}\text { Jumlah } \\
\text { Usaha } \\
\text { (unit) }\end{array}$ & $\begin{array}{c}\text { Pangsa } \\
(\boldsymbol{\%})\end{array}$ & $\begin{array}{c}\text { Jumlah } \\
\text { Tenaga Kerja } \\
\text { (jiwa) }\end{array}$ & $\begin{array}{c}\text { Pangsa } \\
\mathbf{( \% )}\end{array}$ & $\begin{array}{c}\text { PDB atas } \\
\text { Dasar Harga } \\
\text { Berlaku (Rp } \\
\text { Miliar) }\end{array}$ & $\begin{array}{c}\text { Pangsa } \\
(\boldsymbol{\%})\end{array}$ \\
\hline Usaha Besar & 5,550 & 0.01 & $3,619,507$ & 3.00 & $5,464,703.2$ & 38.93 \\
Total UMKM & $64,194,057$ & 99.99 & $116,978,631$ & 97.00 & $8,573,895.3$ & 61.07 \\
Usaha Mikro & $63,350,222$ & 96.68 & $107,376,540$ & 89.04 & $5,303,075.7$ & 37.77 \\
Usaha Kecil & 783,132 & 1.22 & $5,831,256$ & 4.84 & $1,347,104.3$ & 9.60 \\
Usaha Menengah & 60,702 & 0.09 & $3,770,835$ & 3.13 & $1,923,715.4$ & 13.70 \\
\hline
\end{tabular}

Sumber: Kementerian Koperasi dan UKM, 2018 (diolah)

Sektor UMKM menjadi sektor usaha di Indonesia yang dinilai mampu untuk berkompetisi dan menjadi pelaku usaha yang unggul terhadap daya saing dan pertumbuhan ekonomi negara (Nasution \& Lubis, 2018). Tabel 1 menunjukkan bahwa UMKM memberikan beberapa kontribusi yang cukup besar terhadap perekenomian nasional di antaranya yaitu kontribusi terhadap Pendapatan Domestik Bruto (PDB) sebesar 8.5 miliar rupiah atau $61.07 \%$ dan penyerapan tenaga kerja kerja sebanyak $116,978,631$ jiwa atau $97 \%$.

Berdasarkan data perusahaan yang tercatat oleh Badan Pusat Statistik (BPS, 2019), jumlah UMKM penyediaan akomodasi dan penyediaan makan minum di Indonesia sebesar 17\%. Angka pertumbuhan industri sektor makanan dan minuman mencapai $7.78 \%$, di mana angka tersebut lebih tinggi dari pertumbuhan industri nonmigas (4.34\%) dan pertumbuhan industri nasional $(5.02 \%)$ (Kementerian Perindustrian, 2019). Hal ini menunjukkan bahwa industri makanan dan minuman di Indonesia dapat terus dikembangkan, termasuk di antaranya adalah Kota Bogor.

Tercatat pada Tabel 2, jumlah UMKM yang tersebar di Kota Bogor adalah 15,364 usaha. UMKM komoditi makanan dan minuman menempati posisi kedua terbesar yaitu sebanyak 4,302 unit setelah komoditi perdagangan sebanyak 5,378 unit (Dinas Koperasi dan UMKM Kota Bogor, 2019). 
Tabel 2 Pembagian jenis komoditi UMKM di Kota Bogor

\begin{tabular}{lc}
\hline Komoditi & Jumlah UMKM \\
\hline Perdagangan & 5,378 \\
Makanan dan Minuman & 4,302 \\
Jasa & 2,304 \\
Tekstil & 1,844 \\
Industri & 1,536 \\
\hline \multicolumn{1}{c}{ Total UMKM } & 15,364 \\
\hline
\end{tabular}

Sumber: Dinas Koperasi dan UMKM Kota Bogor, 2019 (diolah)

Mengacu pada UU No. 33 Tahun 2014 (UU-JPH), setiap perusahaan yang menjual seluruh barang kebutuhan yang dimanfaatkan oleh masyarakat wajib memiliki sertifikat halal dan mencantumkan label halal tidak terkecuali UMKM. Berdasarkan data Lembaga Pengkajian Pangan Obat-obatan dan Kosmetika Majelis Ulama Indonesia (LPPOM MUI) Jawa Barat (2019), jumlah UMKM di Kota Bogor yang telah memiliki sertifikat halal adalah 278 usaha.

Kota Bogor dianggap memiliki peluang yang cukup besar untuk mengembangkan industri pasar halal. Menurut Yunos et al. (2014), industri pasar halal mampu berkembang secara pesat karena aspek demografisnya. Jumlah penduduk di Kota Bogor sebesar 1,096,000 jiwa dan $92 \%$ dari total penduduknya adalah Muslim (BPS Jawa Barat, 2019), sehingga dapat diketahui penduduk Muslim merupakan konsumen terbesar di Kota Bogor. Hal tersebut menjadi sebuah tantangan bagi para pelaku UMKM untuk terus mengembangkan produknya dalam memenuhi kebutuhan terhadap konsumsi produk halal di Kota Bogor.

UMKM di Kota Bogor menunjukkan bahwa para pelaku usaha juga terus berupaya mengembangkan kualitas produknya dan memperluas promosi usahanya. Hal ini dibuktikan dengan penghargaan "Natamukti Ganapravara" yang diberikan oleh International Council for Small Business (ICSB) Indonesia Presidential Award 2019 kepada Kota Bogor. Penghargaan diberikan sebagai bentuk apresiasi kepada kota yang berhasil mempertahankan kinerja positif terhadap perkembangan UMKM daerahnya setiap tahun (Dinas Komunikasi, Informatika, Statistik dan Persandian Kota Bogor, 2019).

Sertifikasi halal produk pangan pada saat ini menjadi garis terdepan yang bertujuan untuk melindungi para konsumen (Salindal et al., 2018). Tidak hanya bagi para konsumen Muslim, namun untuk seluruh konsumen yang saat ini sudah memiliki tingkat kewaspadaan yang lebih tinggi terhadap kebersihan makanan dan dampaknya terhadap kesehatan tubuh (Viverita \& Kusumastuti, 2017). Sertifikat halal berperan untuk mendapatkan kepercayaan konsumen, memperluas pemasaran serta meningkatkan penjualan perusahaan (Yunos et al., 2014). Tidak hanya itu, sertifikat halal menjadi sebuah langkah strategis bagi perusahaan untuk tetap mempertahankan konsumen, menjadi pembeda dengan perusahaan pesaing dan memberikan nilai tambah terhadap produk (Salindal et al., 2018). Menurut Perdana et al. (2018), label halal berdampak positif terhadap peningkatan profit yang diterima oleh perusahaan dikarenakan tingkat kepercayaan konsumen bertambah dengan adanya pencantuman label halal pada produk. Oleh karena itu, dapat dikatakan bahwa peran sertifikat halal penting bagi perusahaan. Di samping menjaga kepercayaan konsumen, sertifikat halal juga berpengaruh terhadap pendapatan atau omzet suatu perusahaan.

Namun, sebagian besar pelaku UMKM di Kota Bogor belum menyadari keuntungan dari sertifikat halal itu sendiri. Sertifikat halal masih dianggap hanya sebagai pemenuhan kewajiban dalam agama Islam, belum melihat dari peluang sertifikat halal yang mampu meningkatkan omzet usaha. Beberapa penelitian yang telah disebutkan sebelumnya menunjukkan bahwa kepemilikan sertifikat halal oleh sebuah perusahaan dapat memengaruhi peningkatan perolehan pendapatan atau omzet usaha. Namun sebagian besar penelitian tersebut masih berfokus pada usaha berskala besar, belum banyak penelitian yang membuktikan pengaruh sertifikat halal terhadap perolehan omzet Usaha Mikro, Kecil dan Menengah (UMKM) khususnya di Kota Bogor. 
Oleh karena itu, pada penelitian ini akan dilakukan analisis pengaruh sertifikat halal terhadap omzet UMKM di Kota Bogor. Analisis yang dilakukan adalah perbandingan perolehan omzet UMKM sebelum memiliki sertifikat halal dengan sesudah memiliki sertifikat halal. Selain itu, penelitian juga akan menganalisis faktor-faktor apa saja yang dapat memengaruhi peningkatan perolehan omzet UMKM setelah memiliki sertifikat halal.

\section{TINJAUAN PUSTAKA}

Halal memiliki arti dibolehkan dalam syariat Islam untuk digunakan atau dilakukan, baik dari cara memperolehnya sampai bentuk benda itu sendiri dan lepas dari unsur yang membahayakannya (Ali, 2016). Perintah bagi Muslim untuk mengonsumsi segala sesuatu yang halal telah tercantum pada Quran surat Al-Baqarah ayat 168. Salah satu upaya yang dapat dilakukan oleh pemerintah di Indonesia untuk melindungi penduduknya dari produk nonhalal adalah dengan kehadiran sertifikat halal produk yang telah diatur pada UU No. 33 Tahun 2014.

Kehadiran UU No. 33 Tahun 2014 tentang Jaminan Produk Halal (UU-JPH) menjadi sumber informasi hukum yang disusun secara efektif untuk mengawal doktrin halalan thayyiban kepada masyarakat (Hidayat \& Siradj, 2015). Berdasarkan UU-JPH, setiap pelaku usaha wajib mencantumkan label halal di kemasan produknya setelah memiliki sertifikat halal. Label halal pada kemasan produk dapat mempermudah konsumen untuk menjamin bahwa produk yang digunakan adalah produk yang halal untuk dikonsumsi. Menurut penelitian Yunos et al. (2014), sertifikat halal berperan untuk mendapatkan kepercayaan konsumen, memperluas pemasaran serta meningkatkan penjualan perusahaan.

Peningkatan penjualan suatu perusahaan akan memengaruhi perolehan omzet usahanya. Sertifikat halal menjadi salah satu faktor yang memiliki pengaruh positif terhadap peningkatan omzet usaha. Hal tersebut dibuktikan pada penelitian Salindal et al. (2018), dengan judul A Structural Equation Model of the Halal Certification and its Business Performance Impact on Food Companies yang menunjukkan bahwa sertifikat halal berpengaruh signifikan terhadap kinerja bisnis perusahaan makanan di Filipina. Kinerja tersebut diukur menggunakan Return on Sales (ROS), Return on Asset (ROA), profitabilitas perusahaan, dan arus kas di luar investasi. Penelitian lainnya dilakukan oleh Wulandari (2018), yaitu Analisis Dampak Program Fasilitas Sertifikasi Halal terhadap Omzet UMKM Makanan dan Minuman di Kabupaten Bogor menunjukkan bahwa terdapat perbedaan nyata antara rata-rata omzet sebelum dan sesudah memiliki sertifikat halal pada UMKM di Kabupaten Bogor.

Terdapat faktor-faktor lain yang mampu memengaruhi perolehan omzet usaha selain sertifikat halal. Penelitian Saryawan et al. (2014) menunjukkan bahwa modal usaha berpengaruh positif terhadap peningkatan perolehan omzet UKM. Modal usaha merupakan keseluruhan biaya yang dibutuhkan untuk keperluan menghasilkan barang/jasa (Mankiw, 2018). Menurut Sitio (2001), modal usaha dapat dibagi menjadi modal investasi dan modal kerja. Pada penelitian ini, modal yang dimaksud adalah modal kerja (bulanan) yang bertujuan untuk menambah kuantitas produk yang dijual. Berdasarkan penelitian Hartono \& Hartomo (2014), modal kerja pada UMKM berpengaruh positif dan signifikan terhadap penjualan dan pendapatan usaha.

Penelitian yang dilakukan oleh Sudirman \& Putra (2015) menunjukkan bahwa tenaga kerja berpengaruh terhadap omzet pelaku usaha warung makan. Selain itu, penelitian Saryawan et al. (2014) membuktikan bahwa variabel jam kerja berpengaruh positif dan signifikan terhadap pendapatan Usaha Kecil dan Menengah (UKM). Hal ini disebabkan penambahan jumlah jam kerja setiap tenaga kerja akan menambah hasil produksi barang/jasa, sehingga semakin tinggi tingkat produksi suatu perusahaan maka semakin tinggi perolehan keuntungan UKM. 
Kemudian menurut penelitian Vijayanti \& Yasa (2017), variabel lama usaha dapat memengaruhi besar pendapatan UMKM karena semakin lama pelaku usaha telah menjalankan usaha tersebut, maka semakin besar pengalaman dan keahlian yang diperoleh. Tidak hanya lama usahanya yang perlu diperhatikan, namun promosi oleh perusahaan juga perlu dilakukan. Promosi melalui internet khususnya media sosial pada saat ini menjadi hal yang cukup digemari para pelaku usaha termasuk pelaku UMKM karena tidak perlu mengeluarkan biaya yang besar (Khairani et al., 2018). Berdasarkan penelitian Khairani et al. (2018), promosi melalui media sosial memiliki tingkat efektivitas yang tinggi terhadap penjualan UMKM makanan dan minuman.

\section{METODE}

Penelitian ini dilaksanakan di Kota Bogor. Pemilihan lokasi dipilih dengan sengaja melalui pertimbangan bahwa Kota Bogor pernah memperoleh penghargaan Natamukti Ganapravara pada tahun 2019. Penelitian dilakukan selama bulan Februari-April 2020. Metode pengumpulan data yaitu dengan pengisian kuesioner dan wawancara secara langsung kepada para pelaku UMKM. Metode sampling yang digunakan adalah pengambilan sampel secara disengaja atau purposive sampling. Menurut Arikunto (2006), jika jumlah populasi lebih dari 100 maka diambil 10\%-15\% dari populasi yang digunakan untuk sampel. Berdasarkan metode penentuan sampel tersebut, jumlah sampel dari total 278 UMKM yang telah memiliki sertifikat halal di Kota Bogor adalah 40 responden. Metode yang digunakan untuk analisis data adalah analisis deskriptif, analisis regresi linear berganda atau Ordinary Least Square (OLS), dan uji-t sampel berpasangan atau paired sample t-test.

\section{Analisis Deskriptif}

Analisis deskriptif adalah metode analisis data yang digunakan untuk menggambarkan atau mendeskripsikan data yang telah terkumpul tanpa adanya tujuan membuat kesimpulan yang berlaku untuk umum atau generalisasi (Muhson, 2006). Pada penelitian ini analisis deskriptif digunakan untuk mengidentifikasi karakteristik responden sebagai pelaku UMKM dan karakteristik usahanya.

\section{Uji-t Sampel Berpasangan}

Uji-t sampel berpasangan (paired sample t-test) merupakan suatu metode pengujian hipotesis terhadap data yang tidak bebas (berpasangan) (Kurniawan, 2008). Pengujian ini sering ditemukan pada satu objek penelitian yang mendapatkan dua perlakuan berbeda. Metode pengujian ini digunakan untuk menguji variabel dependen/omzet UMKM "sebelum" dan "sesudah" memiliki sertifikat halal.

$$
t=\frac{\bar{x}}{\delta / \sqrt{n}} \ldots(1)
$$

Keterangan:

$\bar{x} \quad=$ nilai selisih rata-rata omzet sebelum dan sesudah memiliki sertifikat halal

$\delta \quad=$ standar deviasi dari selisih rata-rata omzet sebelum dan sesudah memiliki sertifikat halal

$n \quad=$ jumlah sampel

Hipotesis:

Bentuk hipotesis yang dirumuskan pada model uji-t sampel berpasangan adalah sebagai berikut (Kurniawan, 2008):

$\mathrm{H}_{0} \quad: \mu$ setelah $=\mu$ sebelum

$\mathrm{H}_{1} \quad: \mu$ setelah $>\mu$ sebelum

Pengambilan keputusan dalam paired sample t-test adalah jika nilai sig. (2-tailed) $<0.05$, maka $\mathrm{H}_{0}$ ditolak dan $\mathrm{H}_{1}$ diterima. Sebaliknya jika nilai sig. (2-tailed) $>0.05$, maka $\mathrm{H}_{0}$ diterima dan $\mathrm{H}_{1}$ ditolak (Kurniawan, 2008). 


\section{Analisis Regresi Linear Berganda}

Analisis regresi linear berganda (Ordinary Least Square/OLS) digunakan untuk melakukan estimasi regresi linear berganda. Metode OLS digunakan untuk mengetahui seberapa besar pengaruh lebih dari satu variabel independen (variabel bebas) terhadap variabel dependen (variabel terikat). Variabel terikat pada penelitian ini adalah pendapatan atau omzet UMKM setelah memiliki sertifikat halal.

Persamaan berikut merupakan model OLS yang digunakan untuk menganalisis faktor-faktor yang memengaruhi omzet UMKM setelah memiliki sertifikat halal:

$L n_{-} Y=\alpha+\beta_{1} L n_{-} M o d a l+\beta_{2} J K+\beta_{3} L U+\beta_{4} D \_P R O+e_{i} \ldots$ (2)

Keterangan:

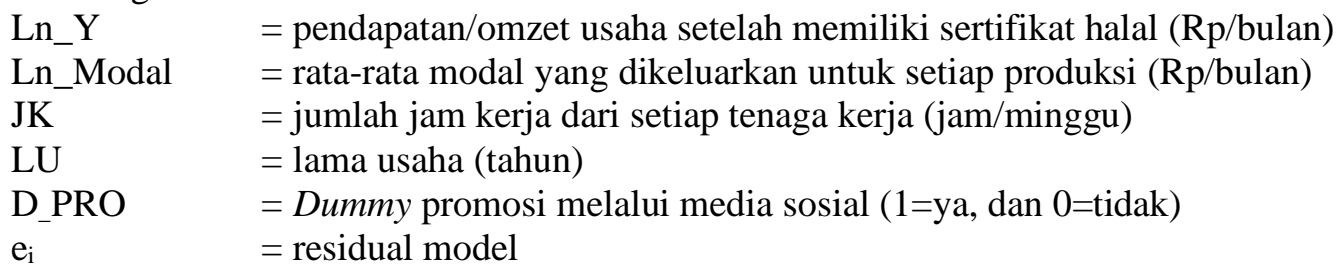

\section{Uji T-statistik}

Uji T-statistik (uji koefisien regresi secara parsial) digunakan untuk mengetahui apakah variabelvariabel independen secara parsial berpengaruh signifikan terhadap variabel dependen. Bentuk hipotesis uji T-statistik sebagai berikut:

$$
\begin{aligned}
& \mathrm{H}_{0}: \beta_{1}=0, \beta_{2}=0, \ldots \beta_{n}=0 \\
& \mathrm{H}_{1}: \beta_{1} \neq 0, \beta_{2} \neq 0, \ldots \beta_{n} \neq 0
\end{aligned}
$$

Jika nilai $t_{\text {hitung }}>t_{\text {tabel }}$ maka $\mathrm{H}_{0}$ ditolak, artinya adalah secara parsial variabel independen tidak berpengaruh signifikan terhadap variabel dependen (Basuki, 2016).

\section{Uji F-statistik}

Uji F-statistik digunakan untuk mengetahui apakah variabel-variabel independen bersama-sama signifikan memengaruhi variabel dependen. Bentuk uji F-statistik sebagai berikut:

$$
\begin{aligned}
& \mathrm{H}_{0}: \beta_{1}=\beta_{2}=\ldots \beta_{n}=0 \\
& \mathrm{H}_{1}: \beta_{1} \neq \beta_{2} \neq \ldots \beta_{n} \neq 0
\end{aligned}
$$

Jika nilai $F_{\text {hitung }}>F_{\text {tabel }}$ maka $\mathrm{H}_{0}$ ditolak, artinya adalah secara bersama-sama antar variabel independen tidak berpengaruh signifikan terhadap variabel dependen (Basuki, 2016).

\section{Koefisien Determinasi yang Disesuaikan (Adjusted $\mathbf{R}^{2}$ )}

Para ahli ekonometrika menemukan bahwa nilai $\mathrm{R}^{2}$ akan terus meningkat apabila menambah jumlah variabel independen walaupun variabel independen tersebut belum memiliki justifikasi secara teori ataupun logika ekonomi, sehingga dikembangkan alternatif lain yaitu koefisien determinasi yang disesuaikan (adjusted $\mathrm{R}^{2}$ ). Koefisiensi determinasi yang disesuaikan (adjusted $\mathrm{R}^{2}$ ) memiliki nilai yang lebih kecil daripada nilai koefisien determinasi $\left(\mathrm{R}^{2}\right)$, digunakan untuk mengukur seberapa besar persentase variasi variabel independen pada model mampu menjelaskan variasi variabel dependen (Basuki, 2016). Adjusted $\mathrm{R}^{2}$ dirumuskan sebagai berikut:

$$
R_{\text {adj }}^{2}=1-\frac{M S E}{M S T}=1-\left(\frac{\sum_{\left(y_{\text {pred }}-y_{\text {rata-rata }}\right)^{2}}}{\sum_{\left(y_{\text {aktual }}-y_{\text {rata-rata }}\right)^{2}}}\right)\left(\frac{n-1}{n-k}\right) \ldots
$$

Keterangan:

$$
\begin{array}{ll}
\text { MSE } & =\text { Mean Squared Error (rata-rata jumlah kuadrat regresi) } \\
\text { MST } & =\text { Mean Squared Total } \text { (rata-rata jumlah kuadrat total) } \\
\mathrm{n} & =\text { jumlah sampel } \\
\mathrm{k} & =\text { jumlah parameter dikurangi } 1(p-1)
\end{array}
$$


Nilai koefisien determinasi yang disesuaikan berada pada interval 0 sampai 1 . Jika nilai adjusted $\mathrm{R}^{2}$ semakin mendekati angka 1 (sempurna), maka hubungan antara seluruh variabel independen terhadap variabel dependen semakin kuat. Sedangkan semakin mendekati angka 0 (tidak ada hubungan sama sekali), maka hubungan semakin lemah (Basuki, 2016).

\section{Pengujian Asumsi Klasik}

Suatu model regresi yang baik adalah model yang tidak mengalami berbagai penyimpangan terhadap berbagai asumsi yang disebut asumsi klasik dan bersifat BLUE (Best Linear Unbiased Estimator) (Basuki, 2016). Beberapa asumsi klasik yang perlu dipenuhi tersebut adalah data terdistribusi normal, bersifat homoskedastisitas, tidak terjadi autokorelasi, dan tidak ada multikolinearitas antar variabel independen. Oleh karena itu, diperlukan uji normalitas, uji heteroskedastisitas, uji autokorelasi, dan uji multikolinearitas.

\section{PEMBAHASAN}

\section{Karakteristik Umum Responden}

Responden pada penelitian ini adalah para pelaku UMKM makanan dan minuman di Kota Bogor yang telah memiliki sertifikat halal. Total pelaku UMKM yang dianalisis sebanyak 40 orang. Karakteristik pelaku UMKM dibagi berdasarkan karakter jenis kelamin, agama, usia, dan pendidikan terakhir.

Tabel 3 Karakteristik umum responden

\begin{tabular}{lccc}
\hline & Karakteristik & $\begin{array}{c}\text { Total Responden } \\
\text { (Orang) }\end{array}$ & Persentase (\%) \\
\hline Jenis Kelamin & Laki-laki & 9 & 22.50 \\
& Perempuan & 31 & 77.50 \\
\hline \multirow{2}{*}{ Agama } & Islam & 38 & 95.00 \\
& Non-Islam & 2 & 5.00 \\
\hline \multirow{4}{*}{ Usia } & $20-25$ & 2 & 5.00 \\
& $26-35$ & 9 & 22.50 \\
& $36-45$ & 9 & 22.50 \\
\multirow{3}{*}{ Pendidikan } & $46-55$ & 17 & 42.50 \\
Terakhir & $56-60$ & 3 & 7.50 \\
& SMA/SMK & 11 & 27.50 \\
& D3 & 7 & 17.50 \\
\hline
\end{tabular}

Sumber: Data primer, 2020 (diolah)

Berdasarkan Tabel 3, sebagian besar pelaku usaha adalah perempuan yaitu sebanyak 31 orang atau $77.5 \%$ dan mayoritas agama yang dianut adalah agama Islam sebanyak 39 orang atau 95\%. Rata-rata usia para pelaku usaha berusia antara 46 hingga 55 tahun, yaitu sebanyak 17 orang atau $42.5 \%$ dan mayoritas pendidikan terakhir yang ditempuh yaitu S1 sebanyak 16 orang atau $47.5 \%$.

\section{Karakteristik Usaha Responden}

Karakteristik usaha yang dijalankan pada penelitian ini diklasifikasikan berdasarkan skala usaha, jenis usaha, status usaha, modal kerja, omzet, lama usaha, jumlah tenaga kerja dan jam kerja, lama memiliki sertifikat halal, sumber perolehan sertifikat halal, sumber informasi sertifikasi halal, alasan memiliki sertifikat halal, dan promosi yang dilakukan pelaku usaha. 


\section{Skala usaha}

Pembagian skala usaha dibagi berdasarkan rata-rata perolehan omzet usaha selama satu tahun. Berdasarkan hasil penelitian, sebagian besar skala usaha yang dijalankan oleh para pelaku usaha adalah usaha mikro yaitu sebanyak 27 usaha atau $67 \%$ dengan rata-rata perolehan omzet setahun kurang dari sama dengan 300 juta rupiah. Usaha berskala kecil dengan rata-rata perolehan omzet setahun lebih dari 300 juta rupiah sampai kurang dari 2.5 miliar rupiah adalah sebanyak 11 usaha atau $28 \%$. Perusahaan berskala menengah dengan rata-rata perolehan omzet setahun lebih dari 2.5 miliar rupiah yaitu sebanyak 2 usaha atau $5 \%$.

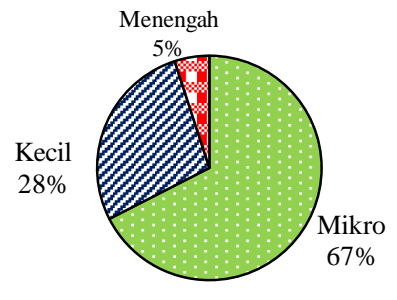

Sumber: Data primer, 2020 (diolah)

Gambar 1 Proporsi skala UMKM pada penelitian

\section{Jenis usaha}

Pelaku UMKM menjalankan usaha pada berbagai jenis makanan dan minuman. Berdasarkan hasil penelitian pada Gambar 2 bahwa sebagian besar usaha yang dijalankan responden berupa kue dan roti sebanyak 14 usaha atau 35\%, kemudian diikuti dengan usaha lainnya seperti cokelat, puding, mochi, pempek, nasi box dan frozen food sebanyak 9 usaha atau 22\%. Terdapat juga kategori minuman yang terdiri dari teh, kopi, susu dan yoghurt sebanyak 7 usaha atau $18 \%$. Lalu usaha keripik sebanyak 5 usaha atau $12 \%$, bumbu masak sebanyak 3 usaha atau $8 \%$ dan usaha sambal sebanyak 2 usaha atau $5 \%$.

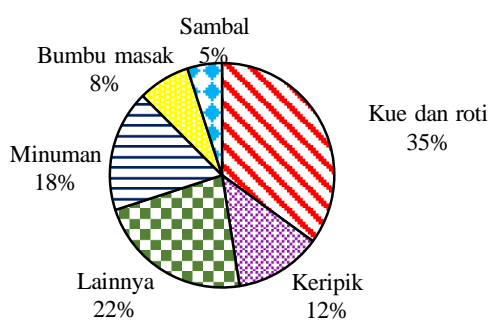

Sumber: Data primer, 2020 (diolah)

Gambar 2 Jenis usaha responden

\section{Sumber penghasilan usaha}

Berdasarkan Gambar 3, sebanyak 26 orang atau $65 \%$ menjadikan pendapatan dari usaha adalah sumber pendapatan utama. Kemudian sebanyak 14 orang lainnya menjalankan usaha tersebut sebagai usaha sampingan atau sebesar $35 \%$. Sumber pendapatan utama responden yang menyatakan usaha sampingan diperoleh melalui pendapatan suami, gaji profesi, dan lainnya. 


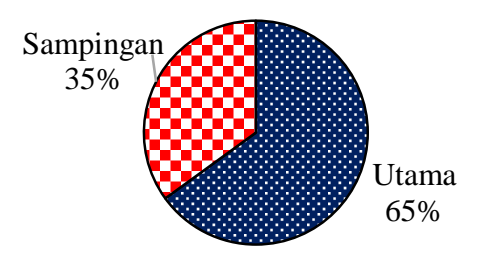

Sumber: Data primer, 2020 (diolah)

Gambar 3 Status sumber penghasilan usaha responden

Modal kerja

Tabel 4 Modal kerja responden

\begin{tabular}{lc}
\hline Nilai & Skala Usaha Mikro \\
Modal Kerja (Rp/bulan)
\end{tabular}

Sumber: Data primer, diolah (2020)

Setiap UMKM di Kota Bogor memiliki modal kerja yang relatif beragam. Berdasarkan Tabel 4, ratarata modal yang harus tersedia oleh pelaku usaha berskala mikro adalah 3 juta rupiah. Kemudian ratarata modal kerja untuk usaha kecil adalah 20 juta rupiah dan rata-rata modal kerja untuk usaha sekala menengah adalah 350 juta rupiah. Pada usaha berskala mikro, minimum modal kerja yang digunakan adalah 1 juta rupiah dan maksimum modal yang digunakan adalah 14 juta rupiah. Kemudian untuk minimum modal kerja yang digunakan pada usaha kecil sebesar 15 juta rupiah dan maksimum modal yang digunakan sebesar 35 juta rupiah. Pada skala usaha menengah, minimum modal kerja yang digunakan adalah 250 juta rupiah dan maksimum modal kerja sebesar 450 juta rupiah.

Perolehan modal kerja sebagian besar dipengaruhi dari hasil penjualan produk kepada konsumen. Modal kerja yang digunakan untuk investasi dalam jangka pendek di antaranya adalah biaya bahan baku, upah tenaga kerja, biaya operasional perusahaan seperti listrik dan air, biaya transportasi, biaya pengiriman barang, serta biaya operasional lainnya. 
Omzet

Tabel 5 Omzet usaha responden

\begin{tabular}{lcc}
\hline Nilai & $\begin{array}{c}\text { Skala Usaha Mikro } \\
\text { Omzet per bulan }(\mathbf{R p})\end{array}$ & Omzet per tahun $(\mathbf{R p})$ \\
\hline Minimum & $2,000,000$ & $24,000,000$ \\
Maksimum & $21,000,000$ & $252,000,000$ \\
Rata-rata & $9,740,741$ & $116,888,889$ \\
\hline & Skala Usaha Kecil & \\
Nilai & Omzet per bulan $(\mathbf{R p})$ & Omzet per tahun $(\mathbf{R p})$ \\
\hline Minimum & $25,000,000$ & $300,000,000$ \\
Maksimum & $75,000,000$ & $900,000,000$ \\
Rata-rata & $41,818,182$ & $501,818,182$ \\
\hline & Skala Usaha Menengah & \\
Nilai & Omzet per bulan $(\mathbf{R p})$ & Omzet per tahun $(\mathbf{R p})$ \\
\hline Minimum & $360,000,000$ & $4,320,000,000$ \\
Maksimum & $900,000,000$ & $10,800,000,000$ \\
Rata-rata & $630,000,000$ & $7,560,000,000$ \\
\hline
\end{tabular}

Sumber: Data primer, 2020 (diolah)

Hasil penelitian pada Tabel 5 menunjukkan bahwa perolehan omzet setiap usaha sangat beragam. Rata-rata omzet yang diperoleh oleh usaha berskala mikro adalah 9 juta rupiah per bulan atau 116 juta rupiah per tahun, omzet usaha kecil adalah 41 juta rupiah per bulan atau 501 juta per tahun, dan omzet usaha menengah sebesar 630 juta rupiah per bulan atau 7 miliar rupiah per tahun. Pada usaha berskala mikro, minimum omzet yang diperoleh sebesar 2 juta rupiah per bulan atau 24 juta rupiah per tahun, sedangkan untuk perolehan omzet maksimum sebesar 21 juta rupiah per bulan atau 252 juta rupiah per tahun. Kemudian untuk usaha berskala kecil, perolehan omzet minimum sebesar 25 juta rupiah per bulan atau 300 juta rupiah per tahun, dan untuk perolehan omzet maksimum sebesar 75 juta rupiah per bulan atau 900 juta rupiah per tahun. Pada skala usaha menengah omzet minimum yang diperoleh sebesar 360 juta per bulan atau 4 miliar rupiah per tahun, untuk omzet maksimum yang diperoleh sebesar 900 juta rupiah per bulan atau 10 miliar rupiah per tahun.

\section{Jam kerja}

Jam kerja adalah lama waktu yang dihabiskan oleh pelaku usaha untuk melakukan kegiatan jual beli barang/jasa dengan tujuan untuk mendapatkan keuntungan. Menurut Mantra (2003), semakin tinggi jam kerja yang digunakan maka akan semakin tinggi pendapatan yang diperoleh.

Tabel 6 Jumlah jam kerja responden

\begin{tabular}{cccc}
\hline $\begin{array}{c}\text { Jumlah jam kerja } \\
\text { (jam/minggu) }\end{array}$ & $\begin{array}{c}\text { Jumlah tenaga } \\
\text { kerja (orang) }\end{array}$ & $\begin{array}{c}\text { Jumlah unit usaha } \\
\text { (unit) }\end{array}$ & Persentase (\%) \\
\hline $84-<150$ & 50 & 20 & 50 \\
$\geq 150-<250$ & 43 & 11 & 27.5 \\
$\geq 250-<350$ & 6 & 1 & 2.5 \\
$\geq 350-<450$ & 24 & 3 & 7.5 \\
$\geq 450-2,142$ & 118 & 5 & 12.5 \\
\hline
\end{tabular}

Sumber: Data primer, 2020 (diolah)

Berdasarkan hasil penelitian, setiap satu orang tenaga kerja dipekerjakan kurang lebih $42-60$ jam per minggu. Diketahui sebagian besar responden menjalankan usahanya selama 84 jam sampai kurang dari 150 jam per minggu. Kemudian jam kerja lebih dari sama dengan 150 jam sampai kurang dari 250 jam adalah $27.5 \%$. Jam kerja selama lebih dari sama dengan 250 jam sampai kurang dari 350 jam per minggu adalah $2.5 \%$. Lalu jam kerja lebih dari sama dengan 350 jam sampai kurang dari 450 jam per minggu sebesar $7.5 \%$ dan jam kerja lebih dari sama dengan 450 jam sampai 2,142 jam kerja per minggu sebesar $12.5 \%$. 


\section{Lama usaha}

Mayoritas lama usaha yang telah dijalankan oleh para pelaku UMKM berada pada rentang $3-6$ tahun yaitu sebanyak 18 usaha atau $45 \%$ dari total responden (Gambar 4). Usaha yang berjalan kurang dari 3 tahun sebanyak 5 usaha atau $12.5 \%$ Kemudian terdapat usaha yang telah berjalan pada rentang $7-9$ tahun sebanyak 11 usaha atau $27.5 \%$. Sebanyak 6 usaha atau $15 \%$ telah menjalankan usaha lebih dari 9 tahun. Usaha UMKM yang telah berjalan paling lama yakni 17 tahun dan usaha yang paling baru berjalan yakni 2 tahun.

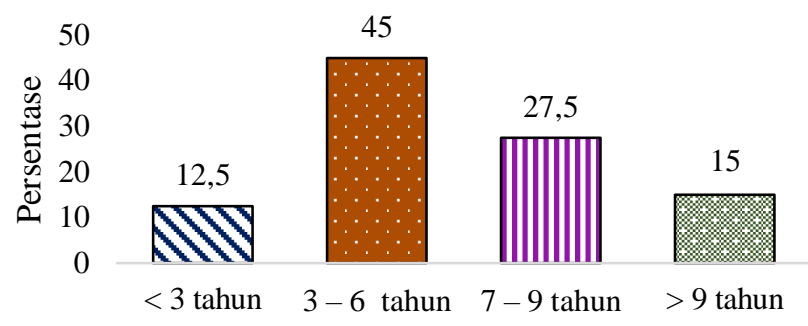

Sumber: Data primer, 2020 (diolah)

Gambar 4 Lama usaha responden

\section{Promosi}

Promosi adalah suatu upaya yang dilakukan pada suatu usaha yang bertujuan untuk memengaruhi konsumen sehingga para konsumen tertarik untuk membeli yang ditawarkan saat ini maupun saat mendatang (Sistaningrum, 2002). Terdapat empat jenis metode promosi yang dapat dilakukan yaitu sales promotion, personal selling, publisitas dan periklanan (Swastha, 2005). Pada saat ini, di mana teknologi semakin berkembang terdapat bentuk lain untuk melakukan promosi yaitu promosi melalui internet atau media sosial. Kehadiran media sosial mempermudah para pelaku usaha untuk melakukan promosi sehingga dapat menjangkau konsumen secara lebih luas.

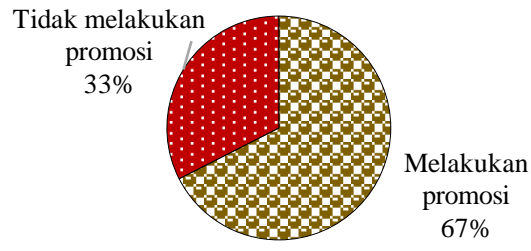

Sumber: Data primer, 2020 (diolah)

Gambar 5 Promosi usaha responden

Berdasarkan Gambar 5, sebagian besar responden yaitu sebanyak 67\% dari total responden melakukan promosi melalui media sosial untuk memperluas penjualannya dan dapat menjangkau konsumen secara luas. Sebanyak 33\% sisanya, responden tidak melakukan promosi melalui media sosial, hanya melakukan kegiatan jual beli seperti biasa dan menerima pesanan khusus di luar jadwal produksi.

\section{Sertifikasi Halal}

\section{Lama memiliki sertifikat halal}

Berdasarkan hasil penelitian (Gambar 6), mayoritas responden telah memiliki sertifikat halal selama 4 sampai 6 tahun yakni sebanyak 20 orang atau 50\%, kemudian diikuti dengan interval 1 sampai 3 tahun sebanyak 15 orang atau $37.5 \%$. Responden yang telah memiliki sertifikat halal lebih dari sama dengan 7 tahun sebanyak 5 orang atau $13 \%$. 


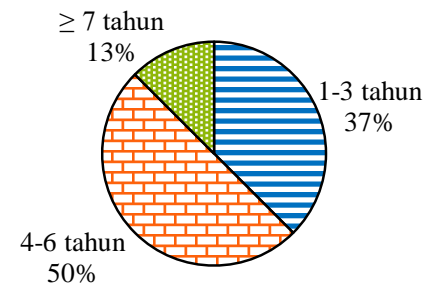

Sumber: Data primer, 2020 (diolah)

Gambar 6 Lama responden memiliki sertifikat halal

\section{Perolehan sertifikat halal}

Mayoritas responden memperoleh sertifikat halal melalui program sertifikasi halal gratis yang diadakan oleh pemerintah daerah Kota Bogor melalui Dinas Perindustrian dan Perdagangan (Disperindag) yaitu sebanyak 19 orang atau 48\% (Gambar 7). Kemudian terdapat responden yang telah menerima fasilitas sertifikasi halal dan memperpanjang secara mandiri sebanyak 13 orang dari total responden penerima fasilitas sertifikasi halal gratis. Terdapat pula responden yang tidak pernah menerima fasilitas sertifikasi halal atau memperoleh sertifikat halal secara mandiri yaitu sebanyak 21 orang atau $52 \%$ dari total responden.

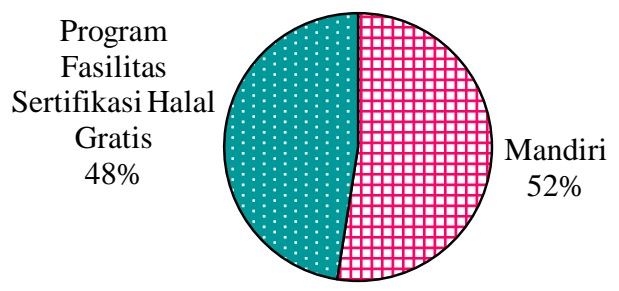

Sumber: Data primer, 2020 (diolah)

Gambar 7 Jumlah responden pemilik sertifikat halal

\section{Sumber informasi sertifikasi halal}

Sebagian besar responden pada penelitian ini mengetahui tentang diperlukannya sertifikat halal pada UMKM melalui sosialisasi program fasilitas sertifikasi halal gratis sebanyak 19 orang atau $47 \%$ (Gambar 8). Kemudian sebanyak 16 orang atau $40 \%$ dari total responden menyatakan mengetahui diperlukannya sertifikat halal melalui komunitas UMKM dan 5 orang lainnya atau $13 \%$ mengetahui dari internet baik melalui website resmi LPPOM MUI, berita, maupun media sosial.

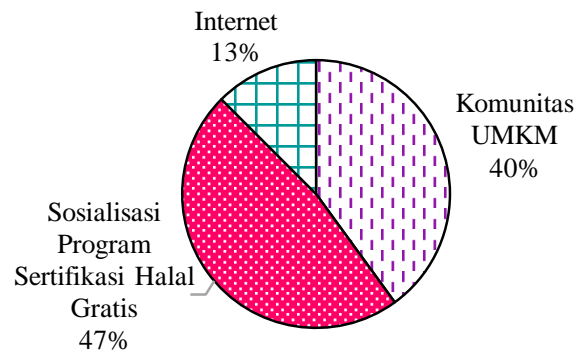

Sumber: Data primer, 2020 (diolah)

Gambar 8 Sumber informasi sertifikasi halal 


\section{Alasan memiliki sertifikat halal}

Berdasarkan Gambar 9, alasan responden memiliki sertifikat halal cukup beragam. Sebagian besar responden menyatakan bahwa dengan adanya sertifikat halal dapat menjaga kepercayaan konsumen yaitu sebesar $27 \%$. Kemudian responden beralasan dengan adanya sertifikat halal responden dapat memperluas pemasaran produk dan meningkatkan omzet bisnis masing-masing sebesar $22 \%$. Sebagian responden juga berpendapat memiliki sertifikat halal untuk mengikuti prinsip berbisnis secara Islami sebesar $15 \%$. Sisanya para responden beralasan karena adanya program fasilitas sertifikasi halal gratis sebanyak $14 \%$.

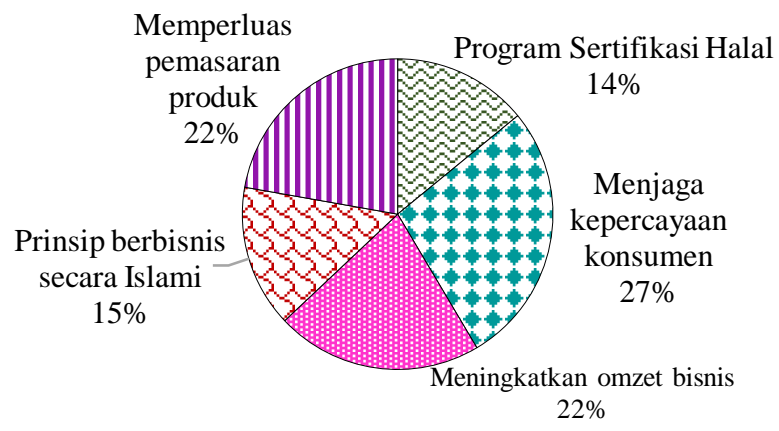

Sumber: Data primer, 2020 (diolah)

Gambar 9 Alasan responden memiliki sertifikat halal

\section{Kendala melakukan sertifikasi halal}

Sebagian besar kendala yang dihadapi oleh para pelaku usaha dalam mengajukan sertifikasi halal adalah biaya yang cukup mahal yaitu sebesar 37\% (Gambar 10). Biaya sertifikasi halal untuk setiap UMKM berbeda, tergantung pada skala usaha, kompleksitas bahan baku yang digunakan serta aspek lainnya. Rata-rata biaya yang harus dikeluarkan untuk usaha mikro dan kecil sebesar 1.5 juta -3 juta rupiah, sedangkan untuk usaha menengah sebesar $3-4$ juta rupiah. Sebanyak 28\% responden mengatakan pengurusan dokumen pengajuan sertifikasi halal cukup sulit. Sebanyak $20 \%$ responden menganggap durasi berlakunya sertifikat halal cukup singkat yaitu hanya 2 tahun. Kemudian sebanyak $9 \%$ responden masih kurang mendapatkan informasi terkait pengajuan sertifikasi halal dan $6 \%$ lainnya menganggap penerbitan sertifikat halal cukup lama.

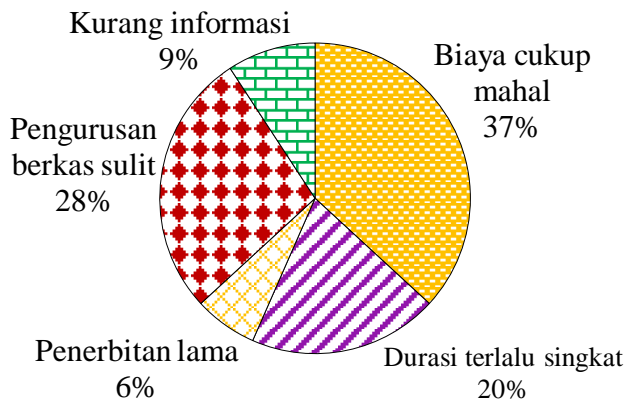

Sumber: Data primer, 2020 (diolah)

Gambar 10 Kendala responden melakukan sertifikasi halal 
Perubahan Omzet UMKM Makanan dan Minuman setelah Sertifikasi Halal di Kota Bogor

Tabel 7 Hasil uji-t sampel berpasangan

\begin{tabular}{lcccc}
\hline \multirow{2}{*}{ Periode } & \multicolumn{3}{c}{ Rata-rata omzet UMKM (Rp/bulan) } \\
\cline { 2 - 5 } & Rata-rata & Minimum & Maksimum & Standar Deviasi \\
\hline $\begin{array}{l}\text { Sesudah memiliki } \\
\text { sertifikat halal }\end{array}$ & $49,450,000$ & $2,000,000$ & $900,000,000$ & $14,910,000$ \\
\hline $\begin{array}{l}\text { Sebelum memiliki } \\
\text { sertifikat halal }\end{array}$ & $37,417,000$ & $1,000,000$ & $720,000,000$ & $11,850,000$ \\
\hline Nilai selisih & $12,033,000$ & $1,000,000$ & $180,000,000$ & $3,060,000$ \\
\hline $\begin{array}{l}\text { Persentase } \\
\text { peningkatan }\end{array}$ & $32 \%$ & & & \\
\hline $\begin{array}{l}\text { Significant (2- } \\
\text { tailed) }\end{array}$ & 0.019 & & & \\
\hline Singer & & & & \\
\hline
\end{tabular}

Sumber: Data primer, 2020 (diolah)

Tabel 7 menunjukkan adanya perbedaan rata-rata antara omzet sebelum dan sesudah memiliki sertifikat halal yaiu sebesar 12 juta rupiah. Hal ini membuktikan bahwa rata-rata omzet setelah memiliki sertifikat halal lebih besar daripada rata-rata omzet sebelum memiliki sertifikat halal. Berdasarkan uji-t sampel berpasangan, nilai sig. (2-tailed) adalah sebesar $0.019<0.05$ sehingga hasil uji-t sampel berpasangan signifikan. Rata-rata perolehan omzet sebelum memiliki sertifikat halal adalah 37,417,000 rupiah, kemudian setelah memiliki sertifikat halal diketahui rata-rata perolehan omzet UMKM sebesar 49,450,000 rupiah. Terdapat peningkatan sebesar 32\% pada rata-rata omzet yang diperoleh UMKM setelah memiliki sertifikat halal.

Berdasarkan hasil penelitian, kepemilikan sertifikat halal menjadi salah satu faktor yang memberikan pengaruh cukup besar terhadap pendapatan UMKM. Kepemilikan sertifikat halal dapat memberikan dan meningkatkan kepercayaan konsumen. Selain itu, sertifikat halal juga dapat membantu para pelaku UMKM untuk memperluas jangkauan pemasarannya, karena dengan adanya sertifikat halal maka produk-produk yang diproduksi oleh UMKM dapat masuk ke toko-toko yang memiliki skala penjualannya lebih besar seperti minimarket dan supermarket. UMKM juga dapat berpartisipasi dalam berbagai acara-acara yang diselenggarakan oleh pemerintah setempat maupun luar wilayah seperti bazar, expo, lomba, dan kegiatan sejenis lainnya. Karena salah satu syarat untuk bisa berpartisipasi dalam kegiatan tersebut adalah sudah memiliki sertifikat halal. Sehingga sertifikat halal dinilai mampu untuk meningkatkan perolehan omzet UMKM.

\section{Faktor-Faktor yang Memengaruhi Peningkatan Omzet UMKM setelah Memiliki Sertifikat Halal}

Pengolahan data yang dilakukan untuk mengetahui faktor-faktor yang memengaruhi omzet UMKM menggunakan analisis regresi berganda atau Ordinary Least Square (OLS) dengan software Eviews 10. Analisis ini digunakan untuk mengetahui faktor-faktor selain sertifikat halal yang dapat memengaruhi omzet UMKM. Model OLS harus melalui uji asumsi klasik atau memenuhi kaidah BLUE (Best Linear Unbiased Estimator). Uji asumsi klasik tersebut di antaranya adalah uji normalitas, uji heteroskedastisitas, uji autokorelasi, dan uji multikolinearitas.

\section{Hasil Pengujian Asumsi Klasik}

\section{Uji normalitas}

Uji normalitas adalah pengujian yang dilakukan untuk mengetahui apakah data penelitian masingmasing variabel terdistribusi secara normal atau tidak. Jika nilai probabilitas yang diperoleh lebih besar dari taraf nyata 5\%, maka data terdistribusi secara normal. Berdasarkan hasil uji normalitas, nilai probabilitas Jarque Bera adalah 0.60, sehingga dapat disimpulkan bahwa data penelitian terdistribusi secara normal dan telah memenuhi asumsi normalitas. 


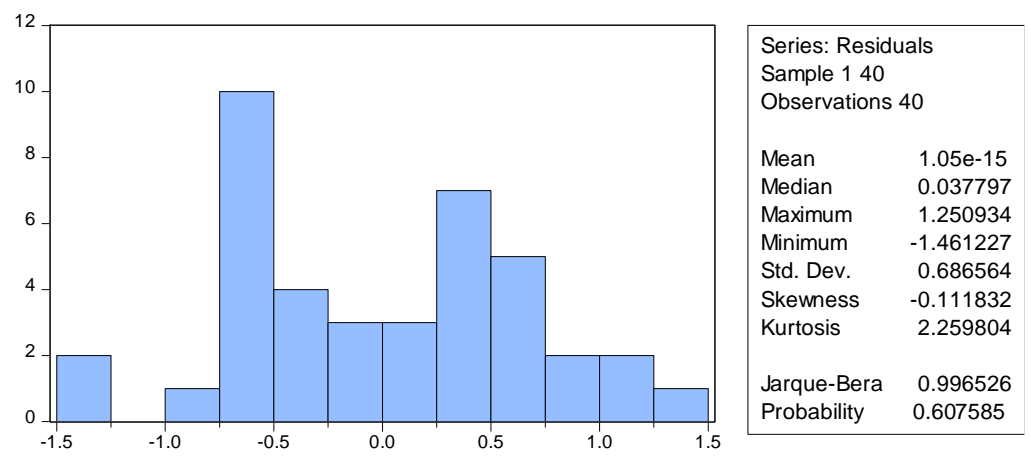

Sumber: Data primer, 2020 (diolah)

Gambar 11 Hasil uji normalitas

\section{Uji heteroskedastisitas}

Uji heteroskedastisitas adalah pengujian yang dilakukan untuk menilai adakah ketidaksamaan varian dari residual untuk semua pengamatan pada sebuah model regresi. Jika nilai probabilitas yang diperoleh lebih besar dari 0.05, maka tidak terjadi heteroskedastisitas pada model. Pengujian heteroskedastisitas dalam penelitian ini menggunakan uji Breusch-Pagan-Godfrey. Berdasarkan hasil uji heteroskedastisitas, nilai probabilitas Chi-Square pada $O b s * R$-Squared adalah 0.12, sehingga dapat disimpulkan bahwa model regresi tidak heteroskedastisitas (homoskedastisitas).

Tabel 8 Hasil uji heteroskedastisitas

\begin{tabular}{lrcc}
\hline F-statistic & 1.901637 & Prob. F $(4,35)$ & 0.1320 \\
Obs $*$-squared & 7.141200 & Prob. Chi-Square(4) & 0.1286 \\
\hline \multicolumn{5}{l}{ Sumber: Data primer, 2020 (diolah) }
\end{tabular}

\section{Uji autokorelasi}

Uji autokorelasi adalah pengujian yang dilakukan untuk mengetahui adakah korelasi variabel yang ada pada sebuah model regresi berdasarkan waktu atau ruang. Jika nilai probabilitas yang diperoleh lebih besar dari 0.05 , maka tidak terjadi autokorelasi pada variabel yang digunakan dalam model. Pengujian autokorelasi menggunakan uji Breusch-Pagan-Godfrey Serial Correlation-LM Test. Berdasarkan hasil uji autokorelasi, nilai probabilitas Chi-Square(2) pada Obs*R-Squared adalah 0.92, sehingga dapat disimpulkan bahwa model regresi tidak ada masalah autokorelasi.

Tabel 9 Hasil uji autokorelasi

\begin{tabular}{|c|c|c|c|}
\hline$F$-statistic & 0.067782 & Prob. F(2,33) & 0.9346 \\
\hline Obs*R-squared & 0.163649 & Prob. Chi-Square(2) & 0.9214 \\
\hline
\end{tabular}

\section{Uji multikolinearitas}

Uji multikolinearitas adalah pengujian yang dilakukan untuk memastikan adanya hubungan linear yang sempurna di antara variabel independen pada model regresi. Jika nilai VIF tidak lebih dari 10, maka tidak terjadi multikolinearitas antar variabel independen. Berdasarkan hasil uji multikolinearitas, nilai Centered VIF seluruh variabel independen kurang dari 2, sehingga dapat disimpulkan bahwa tidak terjadi masalah multikolinearitas.

Tabel 10 Hasil uji multikolinearitas

\begin{tabular}{lccc}
\hline Variable & Coefficient Variance & Uncentered VIF & Centered VIF \\
\hline C & 1.437201 & 109.4507 & NA \\
LN_MODAL & 0.007131 & 120.6905 & 1.170633 \\
JK & $1.87 \mathrm{E}-06$ & 1.644972 & 1.211135 \\
LU & 0.002463 & 7.595496 & 1.286546 \\
D_PROMOSI & 0.070987 & 4.054518 & 1.013630 \\
\hline
\end{tabular}

Sumber: Data primer, 2020 (diolah) 


\section{Hasil Estimasi Regresi Linear Berganda}

Tabel 11 Hasil estimasi faktor-faktor yang memengaruhi omzet UMKM

\begin{tabular}{lcc}
\hline Variabel & Koefisien & Probabilitas \\
\hline Konstanta & 7.070823 & 0.0000 \\
Ln Modal & 0.564360 & $0.0000^{* *}$ \\
Jam Kerja & 0.005644 & $0.0002^{* *}$ \\
Lama Usaha & 0.100055 & $0.0515^{*}$ \\
Dummy Promosi & 0.464708 & $0.0899^{*}$ \\
\hline R-Squared & & 0.777553 \\
\hline Adjusted R-Squared & & 0.752131 \\
\hline Prob (F-statistic) & & 0.000000
\end{tabular}

Sumber: Data primer, 2020 (diolah)

Keterangan: * signifikan pada taraf nyata $10 \%$

** signifikan pada taraf nyata $5 \%$

Hasil estimasi dan uji signifikansi pada model dapat dilihat pada Tabel 11. Jika nilai probabilitas Fstatistik kurang dari 0.05 , maka terdapat pengaruh nyata variabel-variabel dependen terhadap variabel independen. Berdasarkan Tabel 11, nilai probabilitas F-statistik sebesar $0.000 * * *$, sehingga dapat disimpulkan bahwa secara bersama-sama antar variabel independen, yaitu modal usaha, jam kerja, lama usaha, dan dummy promosi berpengaruh signifikan terhadap variabel dependen yaitu omzet. Nilai Adjusted $R$-Squared yang diperoleh dari hasil estimasi sebesar 0.75 artinya keragaman yang mampu dijelaskan oleh faktor-faktor dalam model sebesar $75 \%$ sedangkan sisanya dijelaskan oleh variabel lain di luar model yang diteliti.

\section{Pengaruh Modal Kerja terhadap Omzet}

Berdasarkan hasil estimasi regresi berganda, variabel modal kerja berpengaruh positif pada model dan signifikan pada taraf nyata 5\% dengan koefisien 0.56. Arti dari koefisien tersebut adalah setiap peningkatan rata-rata modal kerja sebesar 1 juta rupiah maka akan meningkatkan rata-rata omzet UMKM sebesar 0.56 satuan rupiah dalam sebulan dengan asumsi cateris paribus.

Modal kerja yang diinvestastikan oleh perusahaan untuk biaya operasional jangka pendek seperti biaya bahan baku, upah tenaga kerja, biaya listrik dan air, biaya transportasi dan biaya lainnya akan memengaruhi tingkat kemampuan sebuah perusahaan dalam melakukan produksi. Semakin besar modal kerja yang tersedia maka semakin besar kuantitas barang yang diproduksi dan dijual, sehingga mampu meningkatkan pendapatan perusahaan. Hasil penelitian ini sesuai dengan hipotesis yang ditetapkan dan sejalan dengan penelitian yang dilakukan oleh Dewi \& Utari (2014), bahwa modal berpengaruh positif dan signifikan terhadap pendapatan UMKM. Menurut Dewi \& Utari (2014), semakin besar modal suatu perusahaan maka akan berpengaruh positif terhadap pendapatan yang diterima.

\section{Pengaruh Jumlah Jam Kerja terhadap Omzet}

Variabel jumlah jam kerja berpengaruh positif pada model dan signifikan pada taraf nyata 5\% dengan koefisien 0.005 . Arti dari koefisien tersebut adalah setiap peningkatan rata-rata lama usaha sebesar 1 jam kerja, maka akan meningkatkan rata-rata omzet UMKM sebesar 0.005 satuan rupiah dalam sebulan dengan asumsi cateris paribus.

Jumlah tenaga kerja yang bekerja pada suatu perusahaan dapat memengaruhi jumlah barang yang diproduksi begitupun dengan jumlah jam kerjanya. Sehingga semakin banyak tenaga kerja dan jumlah jam kerja yang dihabiskan untuk bekerja, semakin meningkat produksi barangnya sehingga dapat memengaruhi peningkatan omzet perusahaan. Hasil penelitian ini sesuai dengan hipotesis yang ditetapkan dan sejalan dengan penelitian yang dilakukan oleh Saryawan et al. (2014) yang menyatakan bahwa jam kerja berpengaruh positif dan signifikan terhadap omzet usaha. Maheswara $e t$ 
al. (2016) menyatakan bahwa semakin lama waktu buka atau operasional perusahaan maka akan semakin besar produk yang dapat terjual sehingga berpengaruh terhadap pendapatan yang diperoleh.

\section{Pengaruh Lama Usaha terhadap Omzet}

Variabel lama usaha berpengaruh positif pada model dan signifikan pada taraf nyata $10 \%$ dengan koefisien 0.10. Arti dari koefisien tersebut adalah setiap peningkatan rata-rata lama usaha sebesar 1 tahun usaha, maka akan meningkatkan rata-rata omzet UMKM sebesar 0.10 satuan rupiah dalam sebulan dengan asumsi cateris paribus.

Setiap pelaku usaha memiliki cara tersendiri untuk menjalankan usahanya, untuk menjalankan usaha dengan baik maka diperlukan berbagai pengalaman selama menjalankan usaha. Semakin lama pelaku usaha menjalankan usahanya, maka akan semakin bertambah pengalaman menjalankan usahanya yang mampu meningkatkan perolehan omzet usahanya. Hasil penelitian ini sesuai dengan hipotesis yang ditetapkan dan sejalan dengan penelitian yang dilakukan oleh Vijayanti \& Yasa (2017) yang menyatakan bahwa lama usaha berpengaruh positif dan signifikan terhadap omzet usaha. Vijayanti \& Yasa (2017) menunjukkan bahwa tingkat keahlian pelaku usaha dapat dipengaruhi oleh lama pelaku usaha dalam menekuni usaha perdagangan. Selain itu, perusahaan juga telah memiliki citra yang baik di mata pelanggan, sehingga perusahaan dapat dengan mudah untuk melakukan proses pendistribusian barang.

\section{Pengaruh Promosi terhadap Omzet}

Variabel dummy promosi berpengaruh positif pada model dan signifikan pada taraf nyata $10 \%$ dengan koefisien 0.46. Arti dari koefisien tersebut adalah UMKM yang melakukan promosi melalui media sosial mampu meningkatkan omzet usahanya sebesar 0.46 satuan rupiah dibandingkan dengan UMKM yang tidak melakukan kegiatan promosi melalui media sosial dengan asumsi cateris paribus.

Kegiatan promosi oleh pelaku usaha terhadap produk yang dijualnya mampu memengaruhi tingkat penjualannya. Semakin besar upaya pelaku usaha untuk mengenalkan produknya kepada masyarakat, maka akan semakin besar peluang dikenalnya produk tersebut oleh masyarakat sehingga mampu menarik masyarakat untuk membeli produk tersebut. Hasil penelitian ini sesuai dengan hipotesis yang ditetapkan dan sejalan dengan penelitian Khairani et al. (2018) yang menyatakan bahwa kegiatan promosi melalui media sosial dapat memperluas jangkauan penjualan dan menarik lebih banyak konsumen. Menurut Setiawati \& Widyartati (2017), UMKM yang melakukan pemasaran secara online mampu meningkatkan omzet usaha karena mampu menjangkau konsumen secara lebih luas.

\section{SIMPULAN}

Berdasarkan hasil estimasi uji-t sampel berpasangan menunjukkan bahwa terdapat perubahan omzet sebelum dan sesudah sertifikasi halal yaitu rata-rata omzet sesudah sertifikasi halal lebih besar daripada rata-rata omzet sebelum sertifikasi halal. Namun, para pelaku UMKM juga menghadapi berbagai kendala yang cukup besar dalam proses pengajuan sertifikasi halal, di antaranya adalah biaya yang cukup mahal, pengurusan berkas yang sulit, dan durasi sertifikat halal yang singkat. Oleh karena itu, diharapkan lembaga yang berkaitan dapat mengatasi berbagai kendala tersebut seperti menurunkan biaya sertifikasi halal, mempermudah pengurusan berkas, dan memperpanjang durasi sertifikat halal sehingga jumlah UMKM yang memiliki sertifikat halal di Kota Bogor dapat terus meningkat.

Faktor-faktor yang memengaruhi peningkatan perolehan omzet UMKM setelah memiliki sertifikat halal adalah modal, jam kerja, lama usaha, dan promosi. Modal, jam kerja, lama usaha dan promosi berpengaruh positif terhadap omzet setelah memiliki sertifikat halal. 


\section{DAFTAR PUSTAKA}

Ali, M. (2016). Konsep makanan halal dalam tinjauan syariah dan tanggung jawab produk atas produsen industri halal. Ahkam: Jurnal Ilmu Syariah, 16(2), 291-306.

Alquran dan Terjemah Tajwid. (2012). Bandung (ID), Penerbit Cordoba.

Arikunto, S. (2006). Prosedur Penelitian. Jakarta (ID), Rineka Cipta.

Basuki, A. T. (2016). Pengantar Ekonometrika (Dilengkapi Penggunaan Eviews). Sleman (ID), Danisa Media.

[BPS] Badan Pusat Statistik. (2019). Provinsi Jawa Barat dalam Angka 2019. Bandung (ID), Badan Pusat Statistik Provinsi Jawa Barat.

[BPS] Badan Pusat Statistik. (2019). Statistik Indonesia 2019. Jakarta (ID), Badan Pusat Statistik Indonesia.

Dewi, N. P. M. \& Utari, T. (2014). Pengaruh modal, tingkat pendidikan dan teknologi terhadap pendapatan usaha mikro kecil dan menengah (UMKM) di Kawasan Imam Bonjol Denpasar Barat. E-Jurnal Ekonomi Pembangunan Universitas Udayana, 3(12), 576-585.

[Diskominfostandi] Dinas Komunikasi, Informatika, Statistik dan Persandian Kota Bogor. (2019). Kota Bogor Sabet Tiga Penghargaan di Natamukti Award 2019 [Internet]. [diunduh 2019 Nov 22]. Tersedia pada: https://kotabogor.go.id/index.php/show_post/detail/13363/kota-bogorsabet-tiga-penghargaan-di-natamukti-award-2019.

[Diskopumkm] Dinas Koperasi dan UMKM Kota Bogor. (2019). Statistik UMKM Kota Bogor [Internet]. [diunduh 2019 Nov 19]. Tersedia pada: http://kumkm.kotabogor.go.id/new/page.php ?buka=umkm.

Hartono \& Hartomo, D. D. (2014). Faktor-faktor yang mempengaruhi perkembangan UMKM di Surakarta. Jurnal Bisnis dan Manajemen Universitas Negeri Semarang (UNS Journal of Business and Management), 14(1), 15-30.

Hidayat, A. S. \& Siradj, M. (2015). Sertifikasi halal dan sertifikasi non halal pada produk pangan industri. Ahkam: Jurnal Ilmu Syariah, 15(2), 199-210.

[Kemenkop \& UKM] Kementerian Koperasi dan UKM. (2018). Perkembangan Data Usaha Mikro, Kecil, Menengah (UMKM) dan Usaha Besar (UB) Tahun 2017-2018 [Internet]. [diunduh 2019 Nov 21]. Tersedia pada: http://www.depkop.go.id/data-umkm.

[Kemenperin] Kementerian Perindustrian. (2019). Industri Makanan dan Minuman jadi Sektor Kampiun [Internet]. [diunduh 2019 Des 20]. Tersedia pada: https://kemenperin.go.id/artikel/202 98/Industri-Makanan-dan-Minuman-Jadi-Sektor-Kampiun-.

Khairani, Z., Sofiyant, E. \& Aznuriyandi, A. (2018). Efektivitas promosi melalui instagram pada UMKM makanan dan minuman di Kota Pekanbaru. Jurnal Benefita: Ekonomi Pembangunan, Manajemen Bisnis \& Akuntansi, 3(2), 239-247.

Kurniawan, D. (2008). Uji t berpasangan (Paired t-test) [Internet]. [diunduh 2020 Apr 21]. Tersedia pada: https://ineddeni.files.wordpress.com/2008/03/uji-t-berpasangan.pdf.

[LPPOM MUI JABAR] Lembaga Pengkajian Pangan Obat-obatan dan Kosmetika Majelis Ulama Indonesia Jawa Barat. (2019). Jumlah Data Sertifikasi Halal untuk KUKM Kota Bogor yang Telah Dikeluarkan oleh LPPOM MUI Jawa Barat Tahun 2015-2019.

Maheswara, A. A. N. G., Setiawina, N. D., \& Saskara, I. A. N. (2016). Analisis faktor-faktor yang mempengaruhi pendapatan UKM sektor perdagangan di Kota Denpasar. E-jurnal Ekonomi dan Bisnis Universitas Udayana, 5(12), 4271-4298.

Mankiw, N. G. (2018). Pengantar Ekonomi Mikro Ed ke-7. Sungkono, C., penerjemah. Jakarta (ID), Salemba Empat. Terjemahan dari: Principles of Economics, $7^{\text {th }}$ ed.

Mantra, I. B. (2003). Demografi Umum Ed ke-2. Yogyakarta (ID), Pustaka Pelajar.

Muhson, A. (2006). Teknik Analisis Kuantitatif. Yogyakarta (ID), Universitas Negeri Yogyakarta.

Mullen, K., Williams, R., \& Hunt, K. (2000). Irish descent, religion and food consumption in the west of Scotland. Appetite, 34(1), 47-54.

Nasution, D. P., \& Lubis, A. I. F. (2018). Peranan UKM terhadap pertumbuhan ekonomi di Indonesia. Jurnal Kajian Ekonomi dan Kebijakan Publik, 3(2), 58-66.

Perdana, F. F. P., Jan, M. T., Altunişik, R., Jaswir, I., \& Kartika, B. (2018). A research framework of the halal certification role in purchase intention of Muslim consumers on the food products 
from Muslim majority countries in The Middle East and North Africa. International Journal, $1(2), 15-28$.

[PRC] Pew Research Center. (2015). The Future of World Religions: Population Growth Projections, 2010-2050 [Internet]. [diunduh 2020 Jan 2]. Tersedia pada: https://assets.pewresearch.org/wpcontent/uploads/sites/11/2015/03/PF_15.04.02_ProjectionsFullReport.pdf.

Rochmanto, B. A., \& Widiyanto, I. (2015). Pengaruh pengetahuan produk dan norma religius terhadap sikap konsumen dalam niat mengkonsumsi produk makanan dan minuman halal (Studi kasus di Kota Semarang). Diponegoro Journal of Management, 4(1), 1-12.

Salindal, N. A., Ahmad, M. I., Abdullah, K., \& Ahmad, B. P. (2018). A Structural Equation Model of the halal certification and its business performance impact on food companies. International Journal of Economics, Management and Accounting, 26(1),185-206.

Saryawan, M., Sudirman, W., \& Yasa, I. G. W. M. (2014). Analisis pengaruh modal usaha, jam kerja dan teknologi terhadap tingkat keuntungan UKM di Kecamatan Denpasar Utara. E-Jurnal Ekonomi Pembangunan Universitas Udayana, 3(3), 122-130.

Setiawati. I., \& Widyartati, P. (2017). Pengaruh strategi pemasaran online terhadap peningkatan laba UMKM. Publikasi Jurnal Ilmiah dalam Menyikapi Permenristekdikti RI No 20 Tahun 2017. Semarang (ID), STIE Dharmaputra Semarang.

[SG] Salaam Gateway. (2019). State of the Global Islamic Economy Report [Internet]. [diunduh 2019 Nov 16]. Tersedia pada: https://salaamgateway.com/reports/report-state-of-the-global-islamiceconomy-201920.

Sistaningrum, E. (2002). Manajemen Penjualan Produk. Yogyakarta (ID), Kanisius.

Sitio, A. (2001). Koperasi Teori dan Praktik. Jakarta (ID), Penerbit Erlangga.

Sucipto, S. (2012). Halal dan haram menurut Al-Ghazali dalam kitab Mau'idhotul Mukminin. ASAS, $4(1)$.

Sudirman, I. W. \& Putra, I. P. D. (2015). Pengaruh modal dan tenaga kerja terhadap pendapatan dengan lama usaha sebagai variabel moderating. E-jurnal Ekonomi Pembangunan Universitas Udayana, 4(9).

Swastha, B. (2005). Manajemen Penjualan. Yogyakarta (ID), Liberty.

Vijayanti, M. D., \& Yasa, I. G. W. M. (2017). Pengaruh lama usaha dan modal terhadap pendapatan dan efisiensi usaha pedagang sembako di pasar kumbasari. E-Jurnal Ekonomi Pembangunan Universitas Udayana, 5(12), 1539-1566.

Viverita \& Kusumastuti, R. D. (2017). Awareness of halal certification of Micro and Small Enterprises in Jakarta. International Journal of Economics and Management, 11(2), 459-471.

Wulandari, A. A. (2018). Analisis Dampak Program Fasilitas Sertifikasi Halal terhadap Omzet UMKM Makanan dan Minuman di Kabupaten Bogor. (Skripsi, Institut Pertanian Bogor, Bogor, Indonesia).

Yunos, R. M., Mahmod, C. F. C., \& Mansor, N. H. A. (2014). Compliance to halal certification-its impact on business financial performance. Recent Trends in Social and Behaviour SciencesProceedings of the 2nd International Congress on Interdisciplinary Behavior and Social Sciences 2013, ICIBSoS 2013, 499-503. 